\title{
Pregnancy rates and metabolic profiles in cattle treated with propylene glycol prior to embryo transfer
}

\author{
Carlos Olegario Hidalgo ${ }^{\mathrm{a}}$, Enrique Gómez ${ }^{\mathrm{a}, *}$, \\ Lupicinio Prieto $^{a}$, Paloma Duque ${ }^{\mathrm{a}, 1}$, Félix Goyache ${ }^{\mathrm{a}}$, \\ Lina Fernández ${ }^{\mathrm{b}}$, Itziar Fernández ${ }^{\mathrm{a}, 2}$, \\ Nieves Facal ${ }^{\mathrm{a}}$, Carmen Díez ${ }^{\mathrm{a}}$ \\ a Area de Genética y Reproducción, Servicio Regional de Investigación y Desarrollo \\ Agroalimentario (SERIDA), Camino de los Claveles 604, Gijón 33203, Spain \\ ${ }^{\mathrm{b}}$ Facultad de Veterinaria. Campus de Vegazana s/n, Leon 24071, Spain
}

Received 26 September 2003; received in revised form 14 November 2003; accepted 15 November 2003

\begin{abstract}
The objective of this study was to determine the effect of a sustained propylene glycol administration to recipients of frozen/thawed in vivo derived bovine embryos. Heifers were treated with oral propylene glycol for the last 20 days before embryo transfer $(n=142)$, and untreated as controls $(n=133)$. Progesterone, insulin, insulin-like growth factor-I, glucose, urea and triglyceride were analysed in blood on Day 0 and Day 7 of the estrous cycle corresponding to embryo transfer. The heifers were selected as recipients when showing progesterone levels $<2.0 \mathrm{ng} / \mathrm{ml}$ (Day 0) and $>2.5 \mathrm{ng} / \mathrm{ml}$ (Day 7), according to corpus luteum quality on Day 7 by technicians unaware of animals treated.

Within treated animals, significantly more recipients were selected, and increased progesterone, corpus luteum quality, pregnancy and calving rates were recorded. Day 7 progesterone concentrations were higher in heifers treated and transferred. Propylene glycol increased insulin and insulin-likegrowth factor-I, but glucose, urea and triglyceride did not vary.

Furthermore, insulin-like-growth factor-I, glucose and triglyceride increased at estrous time, but urea decreased and insulin remained unaltered. Together with the sustained gain in pregnancy rates throughout the experiment ( 2 years), other evidences suggested that the observed effects did not rely on nutritional deficiency. Thus, propylene glycol improved pregnancy rates

\footnotetext{
${ }^{*}$ Corresponding author. Tel.: +34-985195300; fax: +34-985195310.

E-mail address: egomez@serida.org (E. Gómez).

${ }^{1}$ Present address: Centro de Fertilización in vitro de Asturias (CEFIVA), Santa Susana, 31, Oviedo 33007, Spain.

${ }^{2}$ Present address: Consejería de Medio Rural y Pesca, Navia, Asturias, Spain.
} 
after embryo-transfer, and progesterone, insulin and insulin-like-growth factor-I are probably involved in this effect.

(C) 2003 Elsevier Inc. All rights reserved.

Keywords: Propylene glycol; Embryo transfer; Progesterone; Corpus luteum; Metabolic parameters

\section{Introduction}

After superovulation and flushing, embryos collected from a donor female are classified as able to be frozen or transferred. Embryo transfer (ET) is a reproductive tool that allows shortening the generation interval and thus improving the annual genetic gain. At the present time, ET has become a worldwide used technique, but little progress has been achieved during the last decade, especially when pregnancy rates are considered.

Propylene glycol (PPG) is a gluconeogenic precursor largely used by oral administration against ketosis in order to increase the molar percentage of ruminal propionate in postpartum dairy cattle [1-3]. Ketosis results from energy balance deficit, which has a deleterious effects on follicular growth [4,5] and CL activity [5]. After oral administration, a portion of PPG is metabolized to propionate [6], but the majority of PPG escapes the rumen untransformed to be converted to glucose by the liver, primarily via the lactaldehyde pathway and subsequent oxidation to lactate [7]. Propionate is transported to the liver through the portal system, where it is transformed into pyruvate and eventually glucose via oxalacetate $[1,8,9]$. Plasma concentrations of glucose and insulin are known to increase in response to PPG [10,11], although the exact mechanism explaining this has not been established.

It has been suggested that propionate or intermediates of PPG metabolism may stimulate pancreatic insulin secretion [12]. Follicle recruitment [12-14] as well as follicular growth and differentiation [15] are stimulated by insulin, which exerts a beneficial influence on the subsequent embryonic development [16]. Insulin and glucose concentrations are higher in pregnant than in non-pregnant repeat breeding cows [17], and low levels of insulin delay the first ovulation, by acting on follicular development and/or LH secretion in the early postpartum $[13,18]$. Insulin stimulates the in vitro proliferation and function of granulosa $[14,19]$ and thecal cells [20].

Animals receiving oral doses of PPG also show increases in insulin-like growth factor-I (IGF-I) [2,10]. The effects of IGF-I on steroidogenesis, cell proliferation, aromatase activity, folliculogenesis, ovulation, fertilization, implantation and embryonic development has been well documented in mammals [21] and re-visited in the bovine [22]. Changes in insulin are closely related to IGF-I concentrations [23-25]. Together, insulin and IGF-I affect ovarian function and early embryo development by means of a potent stimulation of bovine granulosa cells $[15,26]$, and lead thecal cells to proliferate [26]. On the contrary, with low levels of both IGF-I and insulin, the follicle does not produce adequate levels of estradiol or grow to a size able to trigger the LH surge and ovulation [4].

A minimum amount of $\mathrm{P} 4$ is required to sustain reproductive functions and fertility [27-29], and the main source of P4 in blood from non-pregnant cows is thought to be the CL. Maintenance of P4 synthesis requires insulin, which facilitates lipoprotein utilization in bovine luteal cells [30,31]. In parallel, IGF-I stimulates $\mathrm{P} 4$ production by cultured bovine luteal cells [32-34], and increased IGF-I levels associates to earlier luteal development in 
postpartum cows [35]. In a direct way, IGF-I stimulates CL growth and steroidogenesis [26], and dairy cows showing reduced luteal P4 secretion [36] and anestrous [35,37] exhibit decreased plasma IGF-I. Therefore, P4 could increase in response to insulin and IGF-I, whose concentrations in turn would be higher after a PPG drenching. Experimental treatments in cattle receiving oral PPG are usually longer than $7-14$ days $[2,10,11,13]$.

Based on the ability of IGF-I to stimulate ovarian and uterine function, methods to improve pregnancy rates by using compounds leading to increases of blood IGF-I (recombinant $\mathrm{GH}$ ) have been proposed [38,39], and assayed [40,41], although so far without positive results.

The objective of this study was to determine the capacity of a sustained PPG administration to stimulate reproductive outcomes and pregnancy rates after transfer of frozen/ thawed in vivo derived bovine embryos. In addition, metabolic parameters judged as relevant by their capacity to influence the studied effects (i.e. P4, insulin and IGF-I) were analysed in blood together with glucose, urea and triglyceride.

\section{Materials and methods}

Experiments were carried out from November 2000 up to November 2002 within selected Holstein herds belonging to a local milk recording association. Average temperatures during the experimental period were $+12.2^{\circ} \mathrm{C}$ (from October to April) and $+17.3{ }^{\circ} \mathrm{C}$ (from May to September).

\subsection{Management of animals}

Candidate animals were cyclic heifers aged 15-18-months old, with $350 \mathrm{~kg}$ of required live weight (50-60\% of adult weight) and body condition score of 3-3.5 units (scale of 1-5, where $1=$ emaciated and $5=$ obese). Health status was verified clinically by general and gynaecological examination. Heifers judged to be suitable $(n=286)$ were synchronized with two doses of a synthetic $\mathrm{PGF}_{2 \alpha}$ analogue given at 11 days apart $(2 \mathrm{ml}$ i.m.; Estrumate $^{\circledR}$, Schering-Plough, Germany). Estrus detection (Day 0; 2.5 days after the second $\mathrm{PGF}_{2 \alpha}$ analogue administration on average) was based on a three times per day monitoring of behavioural signs and serum levels of $\mathrm{P} 4$.

\subsection{Selection of recipients}

Selection of recipients was performed 9.5 days after the second $\mathrm{PGF}_{2 \alpha}$ analogue application, immediately before ET. Recipient acceptance focused on time elapsed from standing estrus (6.5-7.5 days), quality of CL and serum levels of P4 on Day 0 and Day 7. A quality score was applied to the CL of each recipient after palpation per rectum by agreement of two experienced ET technicians. Quality 1 (excellent and good) CL had a palpable, external diameter estimated to be $\geq 15 \mathrm{~mm}$, firm or moderately firm consistency and good attachment; the Quality 2 (poor) CL had palpable diameter $<15 \mathrm{~mm}$, or the CL had a soft texture and/or acceptable attachment; the Quality 3 CL (rejected for ET) was scarcely palpable, had a very soft texture and bad attachment. Once allocated to a CL 
Category 1 or 2, selection of recipients for ET required Day 7 P4 serum levels $>2.5 \mathrm{ng} / \mathrm{ml}$ and Day 0 P4 serum levels $<2.0 \mathrm{ng} / \mathrm{ml}[42,43]$.

\subsection{Embryo transfer}

Excellent quality frozen embryos derived from in vivo superovulated high genetic merit cows and heifers, were purchased from a variety of commercial suppliers.

Embryos frozen in $10 \%$ glycerol were thawed and passed through three decreasing dilutions of glycerol with $0.3 \mathrm{M}$ sucrose (Emcare ${ }^{\circledR}$, Immuno-Chemical Products Ltd., Auckland, New Zealand). Embryos frozen in 10\% ethylene glycol were thawed and directly transferred. Embryos were non-surgically transferred to the uterine horn ipsilateral to the ovary bearing the CL, under epidural anaesthesia $(5 \mathrm{ml}, 2 \%$ Lidhocaine chlorhydrate, Laboratorios Ovejero, Leon, Spain).

\subsection{Experimental design}

A farm constituted an experimental unit, where candidate heifers were managed in groups of four or six animals per replicate. The experiment was repeated 58 times in the same number of dairy herds. Half of the animals in each farm were randomly selected to receive one oral daily dose of $250 \mathrm{ml} \mathrm{PPG} \mathrm{(90 \%} \mathrm{purity)} \mathrm{in} \mathrm{the} \mathrm{morning} \mathrm{of} \mathrm{the} \mathrm{last} 20$ days before the predicted ET date, while the remaining half of heifers were not treated and acted as controls. Blood samples were recovered in the morning of Day 0 and Day 7 of estrous cycle corresponding to ET, at the onset of first feed intake and prior to PPG administration. P4 was analysed in all animals used in the trial ( $n=275$ animals; 11 heifers were discarded). Insulin, IGF-I, glucose, urea and triglyceride were investigated in all animals within 21 of the 58 farms on Day 0 ( $n=104$ heifers), out of which 12 farms were also sampled on Day 7 ( $n=59$ heifers).

Groups of two embryos frozen in the same cryoprotectant were assigned to be transferred within a farm/replicate, unless recipients were considered inappropriate upon selection. Embryos were derived from 46 mates (two to four embryos per mate), and the design was randomized by always transferring embryos from different mating within each replicate. One hundred and thirty-eight embryos, frozen in glycerol $(n=22)$ or ethylene glycol $(n=116)$, were thawed and transferred on a blind basis, irrespective of the recipient allocation to the PPG or control group. More than $90 \%$ of recipients transferred were found to be 7-7.5 days after standing estrus. Gestation was palpated per rectum between 38 and 53 days after ET and calving rates were recorded.

\subsection{Blood sampling and serum analyses}

Blood samples were taken early in the morning from venicoccygeal vessels puncture and serum was stored at $-80{ }^{\circ} \mathrm{C}$ until analysed. Day $7 \mathrm{P} 4$ was directly analysed in fresh serum within $2 \mathrm{~h}$ after sampling.

Serum P4 was determined by ELISA by means of Ovucheck Plasma ${ }^{\circledR}$ Kit (Vetoquinol Diagnostics, Spain). The test was sensitive starting from $0.5 \mathrm{ng} / \mathrm{ml}$, and cross-reactivity from steroids other than P4 was lesser than 1\%. Intra- and interassay coefficients of variation were 6 and $7 \%$, respectively. 
Insulin was measured by RIA, using an immunoradiometric assay based on coated-tube separation (BioSource INS-IRMA kit; BioSource Europe, S.A. Nivelles, Belgium). The sensitivity, defined as the apparent concentration two standard deviations above the average counts at zero binding, was $0.1 \mu \mathrm{IU} / \mathrm{ml}$. Cross-reactive hormones were added to a high value standard $(100 \mu \mathrm{IU} / \mathrm{ml}$ or $4 \mathrm{ng} / \mathrm{ml})$ and the apparent insulin response was evaluated. No cross-reaction as detected for samples.

Concentration of IGF-I was determined by RIA (sandwich type) after a pre-treatment step with acid-alcohol in order to improve the clinical performance of the kit, according to the manufacturer (SM-C-RIA-CT kit; BioSource Europe, S.A. Nivelles, Belgium). Briefly, samples of $25 \mu \mathrm{l}$ were incubated with $500 \mu \mathrm{l}$ of acid ethanol solution in 1.5 polypropylene tubes for $30 \mathrm{~min}$. After centrifugation, supernatant was used for the RIA assay. The sensitivity of test was $3 \mathrm{ng} / \mathrm{ml}$. Percentages of cross reaction estimated by comparison of the concentration yielding a 50\% of inhibition were, respectively, 0.2 for IGF-II, $<0.001$ for insulin and $<0.01$ for growth hormone $(\mathrm{GH})$ and epidermal growth factor (EGF).

Radioactivity measurements were performed using a COBRA II Auto-Gamma analyser (Hewlett Packard, USA).

Glucose, urea and triglycerides were determined by colorimetric assay in a Cobas Integra 4000 analyser (Roche, Switzerland) by using commercial kits (Boehringer Mannheim Gmbh, Germany).

\subsection{Statistical analysis}

The following variables have been analysed: pregnancy rates, calving rates (both expressed as frequency percentages of embryos transferred), CL quality, and blood levels of P4, glucose, insulin, IGF-I, urea and triglyceride. Statistical analysis was carried out in two steps. In a first step those effects significantly affecting the analysed variables were identified. Secondly, only fixed effects showing a significant $F$ value were used to fit a linear model using PROC GLM of SAS [44], to estimate least square means and their correspondent standard errors (S.E.). In addition, Duncan's multiple-range test was performed on these main-effect means. The identification of the effects affecting significantly the analysed variables was carried out by means of PROC GLM of SAS [44], except for CL quality, pregnancy rates and calving rates. Because these variables have a categorical definition the identification of the fixed effects affecting them significantly was carried out using PROC CATMOD of SAS [44]. Regardless the procedure used to test the significance of the factors affecting the variables, treatment and farm/replicate were identified to be the only factor affecting them significantly. The other factors tested (embryo origin, cryoprotectant, technician, year and season) did show no significant effect and were excluded from subsequent analysis. In addition, data were submitted to Pearson analysis to calculate correlations.

\section{Results}

As seen in Table 1, quality of CL, as a first choice to select recipients, and P4 levels on Day 7 were significantly higher in heifers receiving PPG, leading to a higher proportion of recipients selected for ET in this group. Pregnancy rates, as well as birth rates (Table 1), 
Table 1

Effect of propylene glycol on Day 7 serum progesterone (P4; ng/ml) and corpus luteum (CL) quality (Day 7) in all animals treated and in recipients transferred, and Day-60 pregnancy rates and calving rates in recipients transferred

\begin{tabular}{|c|c|c|c|c|c|c|c|c|}
\hline \multirow[t]{2}{*}{ Treatment } & \multicolumn{3}{|c|}{ Recipients treated } & \multicolumn{5}{|c|}{ Recipients selected for ET and transferred } \\
\hline & $N$ & P4-Day 7 & CL quality & $\%$ selected $(N)$ & P4-Day 7 & CL quality & $\%$ Pregnancy & Calving rate \\
\hline PPG & 142 & $6.97 \pm 0.25^{\mathrm{x}}$ & $1.42 \pm 0.01^{\mathrm{x}}$ & $69.7^{\mathrm{a}}(83)$ & $7.73 \pm 0.24^{\mathrm{a}}$ & $1.18 \pm 0.06$ & $64.9 \pm 5.6^{\mathrm{c}}$ & $57 \pm 5.6^{\mathrm{c}}$ \\
\hline Untreated & 133 & $5.12 \pm 0.26^{\mathrm{y}}$ & $1.86 \pm 0.01^{\mathrm{y}}$ & $42.2^{\mathrm{b}}(55)$ & $6.01 \pm 0.31^{\mathrm{b}}$ & $1.22 \pm 0.07$ & $43.7 \pm 6.6^{\mathrm{d}}$ & $35 \pm 7.5^{\mathrm{d}}$ \\
\hline
\end{tabular}

Different letters in superscript in columns express significant differences: $(\mathrm{x}, \mathrm{y})(P<0.0001)$; $(\mathrm{a}, \mathrm{b})(P<0.01)$; $(\mathrm{c}, \mathrm{d})$ $(P<0.03) . N$ : numbers of heifers.

Table 2

Day 7 progesterone $(\mathrm{P} 4 ; \mathrm{ng} / \mathrm{ml})$ values arranged by corpus luteum (CL) quality in heifers treated with propylene glycol and controls

\begin{tabular}{lll}
\hline CL quality & Propylene glycol & \\
\cline { 2 - 3 } & Yes $(N)$ & No $(N)$ \\
\hline 1 & $8.10 \pm 0.31^{\mathrm{x}}(93)$ & $6.45 \pm 0.40^{\mathrm{y}}(59)$ \\
2 & $5.38 \pm 0.48^{\mathrm{yz}}(39)$ & $6.39 \pm 0.49^{\mathrm{y}}(36)$ \\
3 & $5.62 \pm 0.88^{\mathrm{yz}}(10)$ & $4.04 \pm 0.48^{\mathrm{z}}(38)$ \\
\hline
\end{tabular}

Different letters in superscript within columns and rows express significant differences: $(\mathrm{x}, \mathrm{y}, \mathrm{z}):(P<0.01)$.

were higher in selected recipients fed with PPG. The beneficial effects of PPG influencing pregnancy, P4 concentration and CL quality, were not dependent on season (data not shown). Quality of CL correlated to P4 levels $(r=-0.43 ; P<0.0001)$, with values equally distributed between both experimental groups. The highest Day 7 P4 levels were recorded on recipients fed with PPG bearing CL Quality 1 (Table 2), in contrast to the similar P4 levels observed between CL Quality 1 and 2 in the controls.

Within recipients transferred $(n=138)$, the PPG group $(n=83)$ showed higher P4 levels on Day 0 than untreated recipients $(n=55)(0.92 \pm 0.10$ versus $0.73 \pm 0.08$; $P<0.05$ ). Recipients that became pregnant (Table 3) exhibited higher P4 levels on

Table 3

Day 0 and Day 7 serum progesterone $(\mathrm{ng} / \mathrm{ml}$ ) concentrations and CL quality in heifers transferred, according to Day 60 pregnancy diagnosis and propylene glycol (PPG) treatment

\begin{tabular}{|c|c|c|c|c|c|}
\hline \multicolumn{2}{|l|}{ Treatment } & \multirow[t]{2}{*}{$N$} & \multicolumn{3}{|l|}{ Progesterone } \\
\hline Pregnancy & PPG & & Day 0 & Day 7 & $\mathrm{CL}$ \\
\hline Non-pregnant & $(-)$ & 31 & $0.76 \pm 0.15$ & $5.77 \pm 0.43^{\mathrm{x}}$ & $1.33 \pm 0.10$ \\
\hline Non-pregnant & $(+)$ & 29 & $0.73 \pm 0.17$ & $6.75 \pm 0.45^{\mathrm{a}}$ & $1.37 \pm 0.11$ \\
\hline Pregnant & $(-)$ & 24 & $0.65 \pm 0.19$ & $5.76 \pm 0.48^{\mathrm{x}}$ & $1.07 \pm 0.11$ \\
\hline Pregnant & $(+)$ & 54 & $1.02 \pm 0.11$ & $8.01 \pm 0.30^{\mathrm{yb}}$ & $1.10 \pm 0.07$ \\
\hline \multicolumn{6}{|l|}{ Cumulative } \\
\hline Non-pregnant & & 60 & $0.75 \pm 0.11^{\mathrm{a}}$ & & $1.35 \pm 0.07^{\mathrm{y}}$ \\
\hline Pregnant & & 78 & $0.83 \pm 0.11^{\mathrm{b}}$ & & $1.08 \pm 0.06^{\mathrm{x}}$ \\
\hline
\end{tabular}

Different letters in superscript in columns express significant differences: $(\mathrm{a}, \mathrm{b})(P<0.05) ;(\mathrm{x}, \mathrm{y})(P<0.01)$. 
Table 4

Influence of propylene glycol (PPG) administration on serum insulin ( $\mu \mathrm{IU} / \mathrm{ml})$, IGF-I (ng/ml), glucose (mg/dl), urea $(\mathrm{mM})$ and triglyceride $(\mathrm{mg} / \mathrm{dl})$ as dependent of cycle day (estrus: Day 0; early luteal: Day 7$)$ in heifers treated (transferred and not transferred)

\begin{tabular}{llllllll}
\hline Cycle day & PPG & $N$ & IGF-I & Insulin & Glucose & Urea & TG \\
\hline Day 0 & $(+)$ & 54 & $303 \pm 13$ & $20.5 \pm 1.7^{\mathrm{x}}$ & $35.7 \pm 3.9$ & $22.4 \pm 0.9^{\mathrm{x}}$ & $23.4 \pm 1.1^{\mathrm{a}}$ \\
& $(-)$ & 50 & $284 \pm 14$ & $16.0 \pm 1.8$ & $42.7 \pm 4.1^{\mathrm{x}}$ & $22.8 \pm 0.9^{\mathrm{x}}$ & $24.8 \pm 1.2^{\mathrm{x}}$ \\
Day 7 & $(+)$ & 30 & $264 \pm 18$ & $20.1 \pm 2.4^{\mathrm{a}}$ & $27.1 \pm 5.0^{\mathrm{y}}$ & $27.2 \pm 1.1^{\mathrm{y}}$ & $19.3 \pm 1.5^{\mathrm{yb}}$ \\
& $(-)$ & 29 & $259 \pm 18$ & $13.0 \pm 2.6^{\mathrm{yb}}$ & $26.6 \pm 4.9^{\mathrm{y}}$ & $26.2 \pm 1.2^{\mathrm{y}}$ & $19.3 \pm 1.6^{\mathrm{yb}}$ \\
\hline
\end{tabular}

Different letters in superscript in columns express significant differences: $(\mathrm{x}, \mathrm{y})(P<0.02)$; $(\mathrm{a}, \mathrm{b})(P<0.05)$

Day 0 and Day 7, and superior CL quality than their non-pregnant counterparts. Pregnant recipients showed higher P4 concentrations only in the PPG group. However, no significant correlations were found between Day 7 P4 and pregnancy rates.

Variations of blood parameters in coincidence with the estrual or early luteal time of the recipient estrous cycle are described in Table 4. Cumulative (PPG + untreated) IGF-I values at estrus $(n=104)$ were higher than on Day $7(n=59)(293 \pm 9.7$ versus $262 \pm 13 ; P<0.05)$, although evidence of PPG influence was found. Thus, IGF-I values on Day 0 in the PPG group tended to be higher than Day 7 in both PPG-treated $(P<0.09)$ and untreated $(P<0.06)$ animals (not shown in table). Cumulative (Day $0+$ Day 7$)$ insulin values increased $(P<0.01)$ when heifers received PPG $(20.3 \pm 1.5$; $n=104)$ as opposed to controls $(14.5 \pm 1.6 ; n=59)$. Glucose levels showed to be cycledependent, although this effect was not obvious in animals fed with PPG. Urea was higher on Day 7 and triglyceride on Day 0, but both compounds were unaffected by the PPG treatment.

As represented in Table 5, insulin was lower in animals untreated and non-pregnant, and remarkably higher in treated with PPG that became pregnant. As opposed, glucose values were higher in pregnant animals independently of the PPG treatment. No variations were

Table 5

Insulin $(\mu \mathrm{IU} / \mathrm{ml})$ and glucose $(\mathrm{mg} / \mathrm{dl})$ values as dependent of pregnancy status and propylene glycol (PPG) treatment of the recipient transferred

\begin{tabular}{|c|c|c|c|c|c|c|}
\hline \multicolumn{2}{|l|}{ Treatment } & \multirow[t]{2}{*}{$N$} & \multicolumn{2}{|l|}{ Insulin } & \multicolumn{2}{|l|}{ Glucose } \\
\hline Pregnancy & PPG & & Day 0 & Day 7 & Day 0 & Day 7 \\
\hline Non-pregnant & $(-)$ & 12 & $14.2 \pm 2.7^{\mathrm{a}}$ & $12.2 \pm 4.1^{\mathrm{x}}$ & $29.7 \pm 3.0$ & $21.6 \pm 5.4$ \\
\hline Pregnant & $(-)$ & 10 & $16.4 \pm 3.0$ & $10.3 \pm 4.1^{\mathrm{x}}$ & $37.3 \pm 4.0$ & $30.5 \pm 5.3$ \\
\hline Non-pregnant & $(+)$ & 11 & $22.8 \pm 2.8^{\mathrm{b}}$ & $19.7 \pm 5.0$ & $29.5 \pm 3.3$ & $21.1 \pm 8.0$ \\
\hline Pregnant & $(+)$ & 20 & $21.7 \pm 2.0^{\mathrm{b}}$ & $27.4 \pm 2.8^{\mathrm{y}}$ & $32.2 \pm 2.6$ & $28.2 \pm 3.5$ \\
\hline \multicolumn{7}{|l|}{ Cumulative } \\
\hline Non-pregnant & & 23 & & & $29.6 \pm 2.5^{\mathrm{x}}$ & $21.3 \pm 4.8^{\mathrm{a}}$ \\
\hline Pregnant & & 30 & & & $34.8 \pm 2.4^{y}$ & $29.3 \pm 3.4^{\mathrm{b}}$ \\
\hline
\end{tabular}

NP: non-pregnant; P: pregnant. Different letters in superscript in columns express significant differences: $(a, b)$ $(P<0.05)$; (x, y) $(P<0.01)$. 
recorded in IGF-I, urea and triglyceride as related to the pregnant status of the recipient (data not shown).

Insulin and glucose correlated on Day $0(+0.57, P<0.0001)$, being this relationship well represented in the control group $(+0.41, P=0.0219)$ but not in the PPG group. This unbalance is comparable to the IGF-I correlation with insulin on Day 0, which is twice in untreated animals $(+0.65, P<0.0001)$ than in their counterparts receiving PPG $(+0.33$, $P=0.0132$ ). Most parameters analysed correlated with IGF-I (Day 0 glucose: +0.25 , $P=0.0345$; Day 7 urea: $+0.29, P=0.0232$; Day 0 triglyceride: $+0.30, P=0.0263$ ), and the marked negative correlation for insulin and urea on Day 0 in the PPG group is in contrast with the total absence of correlation in control animals (data not shown). On Day 0, insulin negatively correlated with urea $(-0.33, P=0.0139)$, while the correlation between glucose and triglyceride was positive $(+0.56, P<0.0001)$.

\section{Discussion}

Propylene glycol treatment increased P4 levels, CL general quality and Day 60 pregnancy rates and calving rates, leading to an optimized use of recipients and being less animals required for synchronization. Although no differences in CL quality were detected between PPG and control animals selected to receive an embryo (i.e. transferred), Day 7 P4 levels were higher in the group of heifers fed with PPG and transferred.

The main source of P4 in blood from non-pregnant cows is thought to be the CL, but P4 can derive from metabolism in the liver and other organs and it is possible an adrenal release [45]. We have not precise explanation about the reason of the higher levels of P4 on Day 0 , but it is a feature from our selection criteria since it occurs only in selected animals from PPG group and in pregnant animals generally. Therefore, we should think in the CL quality as a cause, but correlations between P4 on Day 0 and CL quality were inexistent in this group, so the origin of the differences remains intriguing.

Animals fed with PPG and selected for transfer showed higher P4 concentrations than controls on Day 7, in spite of CL quality was the prevalent standard of judgement for selection. These differences can be explained as animals treated with PPG and bearing Quality 1 CL showed higher P4 concentrations on Day 7. This is in contrast to controls, where comparable P4 concentrations corresponded to heifers bearing Quality 1 and 2 CL. Interestingly, CL quality explained an important part of variation in pregnancy rates at Day 60 ( $r=-0.39)$ and highly correlated with P4 concentrations. However, Day 7 P4 levels from untreated animals did not explain the gain in pregnancy rates, which is opposed to observations from Remsen and Roussel [42], but agrees with other authors [46-48] and with the presence of P4 receptor in the Day 7 bovine embryo [49]. However, unlike the untreated group, recipients fed with PPG that were pregnant had higher P4 concentrations than open recipients. Data from pregnant heifers revealed that CL quality was a useful criterion to select ET recipients as a first choice and, completed with P4 levels, represent a more efficient tool in animals treated with PPG. In contrast to our results, other authors have found that CL quality and pregnancy rates are unrelated [46,50,51]. On the other hand, positive correlations between CL diameter and P4 levels on Day 7 have been reported, but without affecting pregnancy rates $[42,46,47,50]$. 
Apart from increasing P4 levels and improving CL quality, metabolic factors should be considered to explain the gain in pregnancy rates due to PPG observed in the present work. In response to PPG, plasma glucose and insulin concentrations typically increase by 90 min of administration [3,13]. More authors observed similar plasma acute modifications on insulin, IGF-I and glucose levels in animals receiving oral doses of PPG $[2,10]$. According to the above reports, blood sampling within the present work was planned to record non-acute effects of PPG administration (i.e. 24 h lasting from PPG administration), as it was hypothesized that reproductive parameters we studied would be probably more dependent on sustained than short-term effects. We decided to take blood samples at estrus and at day of ET since both are two important reference times from the animal production and science point of view. In addition, the cattle were already gathered and identified, which makes implementation of this program simple. Drenching with $250 \mathrm{ml}$ per day of PPG is expensive, and long-term drenching can be a very intensive labour. The doseresponse for cost-effective therapeutic treatment of heifers remains to be investigated because top dressing PPG may cause reduced feed intake. However, once highly valuable embryos are concerned, administration of PPG would improve the economical outcome for the ET industry, since not only the higher calving rate obtained, but the need to synchronize less numbers of recipients, are important factors to optimize profit.

Energy and protein intake partially controls the performance of the IGF-I system $[4,36,52,53]$. In a variety of species, including humans and farm and laboratory animals, higher concentrations of blood IGF-I are found in young, well nourished, healthy individuals [52,54], whereas low blood IGF-I concentrations are a reflection of a compromised state of tissue, organ and cell function [52,54-56]. In the present work, IGF-I varied with the day of cycle and the PPG treatment, but recipients diagnosed as open did not show concentrations of IGF-I different from pregnant recipients. No changes in IGF-I as dependent on pregnancy status of the recipient is in support of an absence of nutritional deficiency in the animals taking part in the experiments. The sustained beneficial effect of PPG on pregnancy rates and the use of heifers instead of milking cows, contribute as well to discard a nutritional influence from the use of PPG. In addition, using highly expensive embryos in selected herds is a factor contributing to a more careful management and feeding of recipient animals.

The insulin receptor mediates the growth promoting actions of IGF ligands. The insulin receptor belongs to a subfamily of receptor tyrosine kinases that include IGF-I receptor and the insulin receptor-related receptor (IRR) [57]. Insulin, IGF-I and the IRR receptors can form functional hybrids, and at least nine intracellular substrates of the insulin/IGF-I receptor kinases have been identified (reviewed by [58]). Insulin increases glucose transport in fat and muscle cells by stimulating the translocation of the glucose transporter GLUT4 from intracellular sites to plasma membrane [58]. In parallel, in cultured cells glucose leads to an IGF-I increase [59] that regulates glucose by mobilizing glucose transporters GLUT1 [60,61] and GLUT3 [61]. All together, these data may explain the observed tend to reduced Day 0 glucose levels in heifers treated with PPG, in coincidence with the highest insulin and IGF-I concentrations. These higher values in insulin and IGF-I probably remain as a consequence of the immediate response to the high blood glucose acutely induced by PPG $[2,3,10,13]$. The increase in glucose levels at estrus in untreated animals, accompanied by no cycle-related changes in insulin, are in coincidence with 
previous findings in lactating cows [26]. However, the elevated IGF-I values we detected at estrus was reported as non-significant by Alvarez et al. [26], probably because the high number of day $\times$ concentration interactions compared by those authors. In the present study, insulin and glucose correlation observed at estrus in the control group but not in the PPG group suggests an altered glucose regulation by insulin due to propylene glycol.

Urea has been reported to be toxic for oocytes $[53,62]$ and embryos recovered from superovulated cows [63], although cows can recover depending on the period exposure to dietary urea [63]. Anyhow, in our study urea did not change in response to PPG, since it is not dietary energy but protein which negatively correlates with plasma urea $[5,53]$. In contrast to the decreased urea at estrous time we found, Alvarez et al. [26] reported a decrease in urea levels along the estrous cycle. The negative correlation observed in our study coincides with the decrease of urea in milk [64] and plasma [65] induced by insulin. In mature animals a greater concentration of urea is concomitant with greater concentration of IGF-I [26,66,67], which agrees with our correlations, in particular in the group of animals receiving $\mathrm{PPG}$.

Oral administration of PPG increases CL quality and serum progesterone levels, although P4 probably does not increase only at corpus luteum expenses. Upon PPG administration, a higher proportion of recipients were selected for transfer, and pregnancy and calving rates were greater, so the use of PPG can improve economical benefit in the field of ET industry. Thus factors with incidence in the reproductive circuits (i.e. progesterone, insulin and probably IGF-I) are involved in the mechanisms of PPG to improve the results of embryo transfer. Further research is being developed to find the optimal dose and administration protocol before practically used.

\section{Acknowledgements}

Dr. D. Carro for their help to interpret metabolic data. Dr. J.N. Caamaño for critical reading of the manuscript. To farmers from Asturiana de Control Lechero S. Coop. (ASCOL). Supported by Spanish Ministry of Science and Technology, Project AGL-2001-0379.

\section{References}

[1] Emery RS, Brown RE, Black AL. Metabolism of DL-1,2-propanediol- $2^{14} \mathrm{C}$ in a lactating cow. J Nutr 1967;92:348-56.

[2] Grummer RR, Winkler JC, Bertics SJ, Studer VA. Effect of propylene glycol dosage during feed restriction on metabolites in blood of prepartum Holstein heifers. J Dairy Sci 1994;77:3618-23.

[3] Christensen JO, Grummer RR, Rasmussen FE, Bertics SJ. Effect of method of delivery of propylene glycol on plasma metabolites of feed-restricted cattle. J Dairy Sci 1997;80:563-8.

[4] Beam SW, Butler WR. Effects of energy balance on follicular development and first ovulation in postpartum dairy cows. J Reprod Fertil Suppl 1999;54:411-24.

[5] Roche JF, Mackey D, Diskin MD. Reproductive management of postpartum cows. Anim Reprod Sci 2000;60/61:703-12.

[6] Emery RS, Burg N, Brown LD, Blanck GN. Detection, occurrence and prophylactic treatment of borderline ketosis with propylene glycol feeding. J Dairy Sci 1964;47:1074-9. 
[7] Miller ON, Bazzano G. Propanediol metabolism and its relation to lactic acid metabolism. Ann NY Acad Sci 1995;119:957.

[8] Van Soest PJ. Nutritional ecology of the ruminant. New York: Cornell University Press; 1994.

[9] Moore DA, Ishler V. Managing dairy cows during the transition period: focus on ketosis. Vet Med 1997; 92:1061-72.

[10] Studer VA, Grummer SJ, Reynolds CK. Effect of prepartum propylene glycol administration on periparturient fatty liver in dairy cows. J Dairy Sci 1993;76(10):2931-9.

[11] Formigoni A, Cornil M-C, Prandi A, Mordenti A, Rossi A, Portetelle D, et al. Effect of propylene glycol supplementation around parturition on milk yield, reproduction performance and some hormonal and metabolic characteristics in dairy cows. J Dairy Res 1996;63:11-24.

[12] Webb R, Campbell BK, Garverick HA, Gong JG, Gutierrez CG, Armstrong DG. Molecular mechanism regulating follicular recruitment and selection. J Reprod Fertil Suppl 1999;54:33-48.

[13] Miyoshi S, Pate JL, Palmquist DL. Effects of propylene glycol drenching on energy balance, plasma glucose, plasma insulin, ovarian function and conception in dairy cows. Anim Reprod Sci 2001;68:29-43.

[14] Spicer LJ, Chamberlain CS, Maciel SM. Influence of gonadotropins on insulin-and insulin-like growth factor-I (IGF-I) induced steroid production by bovine granulosa cells. Domest Anim Endocrinol 2002;22:237-54.

[15] Spicer LJ, Echternkamp SE. The ovarian insulin and insulin-like growth factor system with an emphasis on domestic animals. Domest Anim Endocrinol 1995;12:223-45.

[16] Telfer EE, Webb R, Moor RM, Gosden RG. New approaches to increasing oocyte yield from ruminants. Anim Sci 1999;68:285.

[17] Selvaraju S, Agarwal SK, Karche SD, Srivastava SK, Majumdar A, Shanker U. Fertility responses and hormonal profiles in repeat breeding cows treated with insulin. Anim Reprod Sci 2002;73:141-9.

[18] Butler WR, Smith RD. Interrelationships between energy balance and postpartum reproductive functions in dairy cattle. J Dairy Sci 1989;72:767-83.

[19] Hernández ER, Resnik CE, Holtzclaw WD, Payne DW, Adashi EY. Insulin a as a regulator of androgen biosynthesis by cultured rat ovarian cells: cellular mechanism(s) underlying physiological and pharmacological hormonal actions. Endocrinology 1988;122:2034-43.

[20] Spicer LJ, Alpizar E, Echternkamp SE. Effects of insulin, insulin-like growth factor-1 and gonadotropins on bovine granulose cell proliferation, progesterone production, and (or) insulin-like growth factor-I production in vitro. J Anim Sci 1993;71:1232-41.

[21] Yoshimura Y. Insulin-like growth factors and ovarian physiology. J Obstet Gynaecol Res 1998;24(5): $305-23$.

[22] Lucy MC. Regulation of ovarian follicular growth by somatotropin and insulin-like growth factors in cattle. J Dairy Sci 2000;83:1635-47.

[23] Beam SW, Butler WR. Energy balance and ovarian follicle development prior to the first ovulation postpartum in dairy cows receiving three levels of dietary fat. Biol Reprod 1997;56:133-42.

[24] Beam SW, Butler WR. Energy balance, metabolic hormones, and early postpartum follicular development in dairy cows fed prilled lipid. J Dairy Sci 1998;82:121-31.

[25] O'Callaghan D, Boland MP. Nutritional effects on ovulation, embryo development and the establishment of pregnancy in ruminants. Anim Sci 1999;68:299-314.

[26] Alvarez P, Spicer LJ, Chase Jr CC, Payton ME, Hamilton TD, Stewart RE, et al. Ovarian and endocrine characteristics during an estrous cycle in Angus, Brahman, and Senepol cows in a subtropical environment. J Anim Sci 2000;78(5):1291-302.

[27] Mann GE, Lamming GE, Robinson RS, Wathes DC. The regulation of interferon- $\tau$ production and uterine hormone receptors during early pregnancy. J Reprod Fertil Suppl 1999;54:317-28.

[28] Mann GE, Lamming GE. Relationship between maternal endocrine environment, early embryo development and inhibition of the luteolytic mechanism in the cow. Reproduction 2001;121:175-80.

[29] Thatcher WW, Moreira F, Santos JEP, Mattos RC, Lopes FL, Pancarci SM, et al. Effects of hormonal treatments on reproductive performance and embryo production. Theriogenology 2001;55:75-90.

[30] Haq I. The role of insulin and insulin related factors on lipoprotein utilization by bovine luteal cells. Thesis. The Ohio State University; 1992.

[31] Poff JP, Fairchild DL, Condon WA. Effects of antibiotics and medium supplements on esteroidogenesis in cultured cow luteal cells. J Reprod Fertil 1998;82:135-43. 
[32] Schams D, Koll R, Li CH. Insulin-like growth factor stimulates oxytocin and progesterone production by bovine granulosa cells in culture. J Endocrinol 1998;116:97-100.

[33] Sauerwein H, Miyamoto A, Gunther J, Meyer HH, Schams D. Binding and action of insulin-like growth factors and insulin in bovine luteal tissue during the oestrous cycle. J Reprod Fertil 1992; 96(1):103-15.

[34] Chakravofty A, Joslyn MI, Davis JS. Characterization of insulin and insulin-like growth factor I actions in the bovine luteal cell: regulation of receptor tyrosine kinase activity phosphatidylinositol-3-kinase, and deoxyribonucleic acid synthesis. Endocrinology 1993;133:1331-40.

[35] Thatcher WW, de la Sota L, Schmitt EJ-P, Díaz TC, Badinga L, Simmen FA, et al. Control and management of ovarian follicles in cattle to optimize fertility. Reprod Fertil Dev 1996;8:203-17.

[36] Spicer LJ, Tucker WB, Adams GD. Insulin-like growth factor-I in dairy cows: relationships among energy balance, body condition, ovarian activity, and estrous behaviour. J Dairy Sci 1990;73:929-37.

[37] Roberts AJ, Nugent RA, Klindt J, Jenkins TG. Circulating insulin-like growth factor I, insulin-like growth factor binding proteins, growth hormone, and resumption of estrus in postpartum cows subjected to dietary energy restriction. J Anim Sci 1997;75:1909-17.

[38] Wilson ME. Premature elevation in serum insulin-like growth factor-I advances first ovulation in rhesus monkeys. J Endocrinol 1998;158:247-57.

[39] Lackey BR, Gray SLL, Hendricks DM. Physiological basis for use of insulin-like growth factors in reproductive applications: a review. Theriogenology 2000;53:1147-56.

[40] Bilby CR, Bader JF, Salfen BE, Youngquist RS, Murphy CN, Garverick HA, et al. IGF-I, and conception rate in cattle treated with low doses of recombinant bovine GH. Theriogenology 1999;51: $1285-96$.

[41] Hasler JF, Bilby CR, Collier RJ, Denham SC, Lucy MC. Effect of recombinant bovine somatotropin on superovulatory response and recipient pregnancy rates in a commercial embryo transfer program. Theriogenology 2003;59:1919-28.

[42] Remsen LG, Roussel JD. Pregnancy rates relating to plasma progesterone levels in recipient heifers at day of transfer. Theriogenology 1982;18:365-72.

[43] Niemann H, Elasaesser F, Sacher B. Pregnancy rates relative to recipient plasma progesterone levels on the day of non-surgical transfer of frozen/thawed bovine embryos. Theriogenology 1985;23:631-9.

[44] SAS Version 8.2. Cary: SAS Institute Inc.; 1999.

[45] Henricks DM, Mayer DT. In: Cole HH, Cupps PT, editors. Reproduction in domestic animals. New York; 1977. p. 72-83.

[46] Hasler JF, McCauley AD, Lathrop WF, Foote RH. Effect of donor-recipient interactions on pregnancy rate in a large scale bovine embryo transfer program. Theriogenology 1987;27:139-68.

[47] Spell AR, Beal WE, Corah LR, Lamb GC. Evaluating recipient and embryo factors that affect pregnancy rates of embryo transfer in beef cattle. Theriogenology 2001;56:287-97.

[48] Chagas e Silva J, Lopes da Costa L, Robalo Silva J. Plasma progesterone profiles and factors affecting embryo-foetal mortality following embryo transfer in dairy cattle. Theriogenology 2003;58:51-9.

[49] Kowalski AA, Rodriguez-Sallaberry CJ, Kramer JM, Moore K. Steroid receptor expression in the early preimplantation bovine embryo. Theriogenology 2003;59:424 [abstract].

[50] Coleman DA, Dailey RA, Leffel RE, Baker RD. Estrous synchronization and the establishment of pregnancy in bovine embryo transfer recipients. J Dairy Sci 1987;70:858-66.

[51] Broadbent PJ, Stewart M, Dolman DF. Recipient management and embryo transfer. Theriogenology 1991;35:125-39.

[52] Thissen JP, Katelslegers JM, Underwood LE. Nutritional regulation of the insulin-like growth factors. Endocrinol Rev 1994;15(1):80-101.

[53] Armstrong DG, Mc Evoy TG, Baxter G, Robinson JJ, Hogg CO, Woad KJ, et al. Effect of dietary energy and protein on bovine follicular dynamics and embryo production in vitro: associations with the ovarian insulin-like growth factor system. Biol Reprod 2001;64:1624-32.

[54] Jones JI, Clemmons DR. Insulin-like growth factors and their binding proteins: biological actions. Endocrinol Rev 1995;16:3-33.

[55] Lucy MC, Beck J, Staples CR, Head HH, De la Sota RR, Thatcher WW. Follicular dynamics, plasma metabolites, and growth factors in lactating cows with positive or negative energy balance during the preestrual period. Reprod Nutr Dev 1991;32:331-41. 
[56] McNall AD, Etherton ED, Fosmire GJ. The impaired growth induced by zinc deficiency in rats associated with decreased expression of the hepatic insulin-like growth factor-I and growth hormone receptor genes. J Nutr 1995;125:874-9.

[57] Patti ME, Kahn CR. The insulin receptor-a critical link in glucose homeostasis and insulin action. J Basic Clin Physiol Pharmacol 1998;9(2-4):89-109.

[58] Saltiel AR, Kahn R. Insulin signalling and the regulation of glucose and lipid metabolism. Nature 2001;414:799-806.

[59] Eter N, Sahm M, Klingmuller D, Spitznas M. Modulation of insulin-like growth factor-I production of cultured retinal vascular endothelial cells by oxigen, glucose and growth hormone. Jpn J Ophthalmol 2002;46:226-9.

[60] Kodaman PH, Behrman HR. Hormone related and glucose sensitive transport of dehydroascorbic acid in immature rat granulosa cells. Endocrinology 1999;140:3659-65.

[61] Fladeby C, Skar R, Serck-Hanssen G. Distinct regulation of glucose transport and GLUT1/GLUT3 transporters by glucose deprivation and IGF-I in chromaffin cells. Biochem Biophys Acta 2003; 1593(2/3):201-8

[62] Sinclair KD, Kuran M, Gebbie FE, Webb R, McEvoy TG. Nitrogen metabolism and fertility in cattle: II. Development of oocytes recovered from heifers offered diets differing in their rate of nitrogen release in the rumen. J Anim Sci 2001;78:2670-80.

[63] Dawuda PM, Scaramuzzi RJ, Leese HJ, Hall CJ, Peters AR, Drew SB, et al. Effect of timing of urea feeding on the yield and quality of embryos in lactating dairy cows. Theriogenology 2002;58:1443-55.

[64] Molento CF, Block E, Cue RI, Petitclerc D. Effects of insulin, recombinant bovine somatotropin, and their interaction on insulin-like growth factor-I secretion and milk protein production in dairy cows. J Dairy Sci 2002;85:738-47.

[65] Mashek DG, Ingvartsen KL, Andersen JB, Vestergaard M, Larsen T. Effects of a four-day hyperinsulinemic-euglycemic clamp in early and mid-lactation dairy cows on plasma concentrations of metabolites, hormones and binding proteins. Domest Anim Endocrinol 2001;21:169-85.

[66] Simpson RB, Chase Jr CC, Spicer LJ, Vernon RK, Hammond AC, Rae DO. Effect of exogenous insulin on plasma and follicular insulin-like growth factor I, insulin-like growth factor binding protein activity, follicular estradiol and progesterone, and follicular growth in superovulated Angus and Brahman cows. J Reprod Fertil 1994;102(2):483-92.

[67] Simpson RB, Chase Jr CC, Spicer LJ, Carroll JA, Hammond AC, Welsh TH. Effects of exogenous estradiol on plasma concentrations of somatotropin, insulin-like growth factor-I, insulin-like growth factor binding protein activity, and metabolites in ovariectomized Angus and Brahman cows. Domest Anim Endocrinol 1997;14:367-80. 